\title{
Fulfilling the journalistic principles of truth and objectivity in the context of mediatisation of political communication - the terrorist attacks in Paris in November 2015
}

\section{Introduction}

In political science, terrorist organisations are categorised as collective political actors. They constitute formalised institutions which possess a specific structure, leaders, ideology, programme, values, and preferences. Unlike public institutions or political parties, they operate outside the law ${ }^{1}$. The influence of the terrorist phenomenon on political communication processes has been growing, however, it constitutes a multi-faceted issue, the interpretation of which is often difficult ${ }^{2}$. Bruce Hoffman in Inside Terrorism stresses the difficulty in offering a clear definition of the essence of terrorism, though he does attempt to indicate its characteristics. According to him, it should be considered as a political con$c e p t^{3}$. He posits that only through that, could one understand the goals and the motivation behind terrorism, and differentiate it from other forms of violence. Katarzyna Maniszewska, a Polish political and media scientist, has noted that many international documents, e.g. the Declaration on Combating Terrorism of 12 December 1995, do not offer a definition of terrorism ${ }^{4}$. The subject literature includes various attempts at a systemic classification of terrorism. For example,

\footnotetext{
* Dr, e-mail: rafalles@vp.pl; Cardinal Stefan Wyszyński University in Warsaw, Department of Theory, Axiology and Media Law.

${ }^{1}$ B. Dobek-Ostrowska, "Komunikowanie polityczne i publiczne", PWN, Warsaw 2012, p. 169.

${ }^{2}$ M. Madej, "Międzynarodowy terroryzm polityczny", Ministerstwo Spraw Zagranicznych, Warsaw 2001, pp. 5-8.

${ }^{3}$ B. Hoffman, "Inside Terrorism", Columbia University Press, New York 2006, p. 2; cf. also R. Borkowski, "Terroryzm ponowoczesny. Studium z antropologii polityki”, Wydawnictwo Adam Marszałek, Torun 2006, pp. 37-40.

${ }^{4}$ K. Maniszewska, "Terroryzm a media. Środki masowego przekazu i literatura a rozwój terroryzmu w Republice Federalnej Niemiec w latach 1968-1998”, Oficyna Wydawnicza „Atut” - Wrocławskie Wydawnictwo Oświatowe, Wroclaw 2006, p. 22.
} 
the FBI, a part of the security system of the USA, defines it as "the unlawful use of force and violence against persons or property to intimidate or coerce a government, the civilian population, or any segment thereof, in furtherance of political or social objectives" . Marek Madej stresses that acts of terrorism are voluntary and intentional acts ${ }^{6}$. Political scientists have tried to classify terrorist organisations. They have indicated, e.g. ideological terrorism (representatives of that included Marx, Lenin, and Mao Zedong), ethnic-nationalist terrorism (e.g. the IRA, the Kurdistan Workers' Party), and political-religious terrorism (Hamas Islamic Resistance Movement, The Islamic Jihad Movement in Palestine) $)^{7}$. That classification refers to the motivations behind the actions of those organisations ${ }^{8}$. Terrorism proves to be an ambiguous notion which depends on the specific location and time in history, and considering the fact that it is studied by the representatives of various sciences who assume different starting points for their deliberations, it should not be surprising how difficult it is for researchers to indicate the most representative and academically proper approach ${ }^{9}$.

An important problem regarding terrorist organisations is their manner of communication with the world through the mass media. The media - terrorism relationship is particularly valid for how public opinion perceives terrorist activities. ${ }^{10}$ Terrorism constitutes a form of political communication which transcends constitutional procedures. It is planned with the aim of exerting a psychological effect on the authorities and society, which is why the mass media are a sine qua non condition for publicising acts of terror ${ }^{11}$. Reports on attacks almost instantaneously become global news. In just a few moments' time after an attack, millions of viewers and internet users become included in a special media spectacle. That applied to the Al-Qaeda 9/11 attacks on the World Trade Center, the attacks on the Moscow Dubrovka Theatre committed on 23-26 October 2002 by a Chechen combat force led by Movsar Basayev, and the series of terrorist attacks on trains in Madrid on 11 March 2004. The media are a source of information on attacks, which does not mean they approve of them or legitimise such actions. The attackers realise the role of the means of communication, which is why they send their statements to the media, or use social media and their own websites to post applicable information. Thus, terrorist organisations want to draw the attention of the global public to the

\footnotetext{
${ }^{5}$ R. Gunaratna, G. Steven, “Counter-Terrorism: A Reference Handbook”, ABC-CLIO, Santa Barbara, California 2004, p. 6.

${ }^{6}$ M. Madej, op. cit., p. 7.

${ }^{7}$ R. Gunaratna, G. Steven, op. cit., pp. 8-10.

${ }^{8}$ M. Madej, op. cit., pp. 22-30.

${ }^{9}$ K. Maniszewska, op. cit., pp. 23-25.

${ }^{10}$ B. Nacos, "Mass-Mediated Terrorism: The Central Role of the Media in Terrorism and Counterterrorism", Lanham, Maryland 2007, pp. 179-192; B. Hoffman, op. cit., pp. 173-228.

${ }^{11}$ A. Peresin, "Mass media and Terrorism", Medijska istraživanja 2007, Vol. 13, Issue 1, pp. 7, 16-18, [5-22] http://hrcak.srce.hr/file/28073 [accessed on: 27.01.2017]; B. Dobek-Ostrowska, op. cit., p. 176.
} 
motivations behind their actions ${ }^{12}$. The media are perceived by those responsible for terrorism as a means of focusing the attention of the receivers ensuring a high level of sensationalism ${ }^{13}$. Therefore, there is a threat that together with the increase of the interest of the media and journalists in the attacks, terrorists will view such a mode of political communication as a form of auto-promotion or advertising, and their activities will escalate. In 2005, the Parliamentary Assembly of the Council of Europe passed a recommendation where they warned journalists against their work being used by terrorists for fulfilling their own needs ${ }^{14}$.

The significance of the media in reporting terrorist attacks can also be expressed in exerting pressure on the authorities to quickly introduce relevant decisions ${ }^{15}$. However, Marek Madej has noted that the media contribute to a minor degree to gaining popularity and political support by terrorist groups. Moreover, attacks in which innocent people die are condemned by the journalistic community, and in no way could one talk about any social acceptance for such behaviour $^{16}$. Also, the media can help in combating terrorist organisations by publishing amongst the general public, the identity and the photographs of persons suspected of having conducted an attack.

The role of the media in reporting on terrorist attacks confirms the gravity of the phenomenon of mediatisation of political communication, in which the media fulfil a two-fold function: of a primary and a secondary sender. On the one hand, they become a channel transporting information without altering the message. On the other, they interpret the message being sent. Teresa Sasińska-Klas emphasises the existence of three paradigms closely related to the mediatisation process: the commonness paradigm, the paradigm of the symbolic world, and the paradigm of the relationship between the media and social changes ${ }^{17}$. In regard to the media - terrorism relationship, the concept appears as follows: the everyday operations of terrorist organisations are associated with and depend on mediatised communication (terrorist organisations communicate both amongst themselves using new communication technologies, and through the mass media, particularly the internet, there occurs an exchange of information between terrorists and society)

${ }^{12}$ B. Dobek-Ostrowska, op. cit., p. 176.

${ }^{13}$ A. Mroczek, "Media", in: "Terroryzm. Anatomia zjawiska", K. Liedel (ed.), Wydawnictwo Naukowe Scholar, Warsaw 2006, pp. 240-243.

${ }^{14}$ T. Goban-Klas, "Dziennikarze i terroryści - przeciwnicy czy wspólnicy?", in: "Między odpowiedzialnością a sensacją. Dziennikarstwo i edukacja na przełomie wieków”, K. Wolny-Zmorzyński, M. Wrońska, W. Furman (eds.), Wydawnictwo Uniwersytetu Rzeszowskiego, Rzeszow 2006, p. 22.

${ }^{15}$ D. Altheide, “The mass media and terrorism”, Discourse \& Communication 2007, Issue 1 (3), pp. 287-308.

${ }^{16}$ M. Madej, op. cit., p. 20.

17 T. Sasińska-Klas, "Mediatyzacja a medializacja sfery publicznej", Zeszyty Prasoznawcze 2014, Issue 2, pp. 164-166. 
Terrorist organisations are viewed through the signs, symbols, and slogans which are communicated to the public by the media (e.g. the Islamic State terrorist organisation is usually presented with an image of a black-and-white flag). Terrorists could not exist without the media, which is why they use the media for fulfilling their goals, and informing society about their activities. The media are an important and necessary forum of public discussion on terrorist organisations.

\section{Research methodology}

I attempt to answer the question whether in the times of the mediatisation of political communication, which in turn means the mediatisation of the communication of the activities of terrorist organisations, the basic principles of journalistic ethics have been observed. The case study covered the press ripples to the series of terrorist attacks in Paris on 13 November 2015. The study material included Polish opinion-making weeklies Newsweek Polska and Polityka, and national dailies: Gazeta Wyborcza and Rzeczpospolita, in their printed versions. The analysis covered all press texts which included at least one of the following terms: terroryzm (terrorism), zamachy terrorystyczne (terrorist attacks), agresja (aggression), przemoc (violence), brutalizm (brutality), Państwo Islamskie (the Islamic State), islam (Islam), and the word Paryz (Paris), paryskie (Paris used as an adjective) or Francja (France). The scope of the study covered the period from 1 November 2015 to 11 December 2015. Thus I gained a representative study sample, which enabled me to establish whether the topic of the terrorist threat in France had appeared in the Polish press prior to 13 Nov 2015, and I could form an objective evaluation of the standards of journalistic work.

The above-mentioned methodological criteria were met by: 5 press articles published in Polityka, 7 texts published in Newsweek Polska, 52 texts published in Gazeta Wyborcza and 55 texts published in Rzeczpospolita ${ }^{18}$.

\section{Quantitative and qualitative analysis}

The study consisted of a quantitative and a qualitative analysis, the goal of which was to define whether the reporting on the Paris attacks respected the two main journalistic principles: the truth and the objectivity principles. Those principles are included in international regulations on journalistic ethics (the

\footnotetext{
${ }^{18}$ In total, 109 press texts met the methodological criteria.
} 
code of the International Union of Press Associations of 1936, the International Federation of Journalists of 1939, the Paris Declaration of 1983, Resolution No. 1003 of the Plenary Assembly of the Council of Europe of 1993) ${ }^{19}$, journalistic ethical codes (e.g. the declaration on the principles of the International Federation of Journalists passed before the $2^{\text {nd }}$ Congress of the International Federation of Journalists in 1954) ${ }^{20}$. The codes of conduct of Polish associations, and extraassociation regulations of professional conduct in Poland also include those basic journalistic principles (e.g. the Code of Journalistic Conduct of the Polish Journalists' Association of 2001, the Journalistic Code of Conduct of the Association of Journalists of the Republic of Poland of 1991, the Media Ethics Charter of 1995, and the Journalistic Code of Conduct of the Conference of the Polish Media of 2002) ${ }^{21}$.

I shall juxtapose the theoretical approach of specific principles of journalistic ethics with their practical applications in the analysed press texts.

\section{The truth principle}

The truth principle requires journalists, publishers, producers, and broadcasters to make every effort to ensure that the communicated information is true, and that the facts are reported reliably, without any distortions, in the appropriate context, and, in the event of an erroneous piece of information, that they introduce corrections immediately ${ }^{22}$.

Based on that understanding of the journalistic truth principle, one can identify a significant criterion for the evaluation of whether a press release observes it or not. That applies to the efforts on the part of the journalists seeking truth, and their scrupulousness in reporting, which is also expressed in correcting possible mistakes and defaming facts.

On 13 November 2015, Paris was the site of a series of terrorist attacks for which responsibility was claimed by Islamic $S_{t a t e}{ }^{23}$. I believe that the study

\footnotetext{
${ }^{19}$ I. Fiut, "Spory o etykę mediów", in: "Spór o etykę. Materiały X Jagiellońskiego Sympozjum Etycznego. Kraków, 4-5 czerwca 1998”, J. Pawlica (ed.), Wydawnictwo Uniwersytetu Jagiellońskiego, Krakow 1999, pp. 66-67; I. Dobosz, "Prawo i etyka w zawodzie dziennikarza”, Oficyna Ekonomiczna Grupa Wolters Kluwer, Warsaw 2008, pp. 109-115.

${ }^{20}$ I. Dobosz, op. cit., pp. $115-116$.

${ }^{21}$ Ibid., pp. 124-129, 131-137.

22 "Karta Etyczna Mediów" (Media Ethics Charter), http://www.radaetykimediow.pl/index. php?option=com_content\&view=category\&layout=blog\&id=2\&Itemid=3 [accessed on: 27.01.2017]; I. Dobosz, op. cit., p. 132.

${ }^{23}$ E. Knecht, "Islamic State says France remains top target", http://www.reuters.com/article/ us-france-shooting-claim-idUSKCN0T30LL20151114 [accessed on: 27.01.2017] ("Islamic State
} 
question whether Polish opinion-making weeklies Newsweek Polska and Polityka and dailies Rzeczpospolita and Gazeta Wyborcza observed the journalistic truth principle, can receive a firm affirmative answer for several reasons.

The first reason was the number of texts within the period directly following the attacks, which showed journalistic care consisting of making every effort to report reliably on the events in Paris. In the week following the attacks, 16-22 Nov 2015, 39 texts were published in Gazeta Wyborcza (a total of 15 texts in the issue of 16 Nov 2015), and 45 texts were published in Rzeczpospolita (18 texts in the issue of 16 Nov 2015) regarding the events in Paris ${ }^{24}$. Two issues of opinion-making weeklies published following the attacks included Newsweek Polska - 1 text in issue 47/2015 and 5 texts in issue 48/2015; and Polityka - 1 text in issue 47/2017 and 2 texts in issue 48/2015. It might seem somewhat surprising that within the period of 1 Nov-13 Nov 2015, the periodicals did not include any texts on the terrorist threat on the part of Islamic State in relation to the capital of France where only a few months prior, in January 2015, there had occurred terrorist attacks in the editorial office of the satirical magazine Charlie Hebdo. That might confirm the assumption that the Polish press considered it a unique and isolated event. On the other hand, the lack of interest on the part of the press in the topic of possible acts of terror in France could be explained by the lengthy period (10 months) that had elapsed since January 2015.

The other reason which shows that the editors of the analysed periodicals made every effort to observe the journalistic truth principle were the detailed accounts of the Paris terrorist attacks and the interviews with specialists on Islam and terrorism ${ }^{25}$.

claimed responsibility on Saturday for attacks that killed 127 people in Paris, saying it sent militants strapped with suicide bomb belts and carrying machine guns to various locations in the heart of the capital"); M. Castillo, M. Haddad, M. Martinez, S. Almasy, CNN, "Paris suicide bomber identified; ISI claims responsibility for 129 dead", http://edition.cnn.com/2015/11/14/ world/paris-attacks/index.html [accessed on: 27.01.2017] ("ISIS claimed responsibility for the horrific Paris attacks, for which France vowed revenge"); J. Gunter, Y. Lukov, T. Poole, H. Low, E. Harrison, T. Spender, "Paris attacks: as they happened", http://www.bbc.com/news/live/worldeurope-34815972 [accessed on: 27.01.2017] ("Islamic State claims responsibility for attacks in official statement").

${ }^{24} 16$ November 2015 was the first day when it was possible to include press reports on the terrorist attacks of 13 November 2015. Considering the fact that the attacks began on Friday the $13^{\text {th }}$ of Nov in the evening, it is no surprise that the first press reactions in dailies in printed versions could only be found on Monday the $16^{\text {th }}$ of Nov.

${ }^{25}$ Press reports from France included, e.g.:

J. Bielecki, "Nowa religia nadziei dla francuskich przedmieść", Rzeczpospolita 2015, 30.11, p. A10.

J. Bielecki, "Śmiertelny wyścig z dżihadem”, Rzeczpospolita 2015, 19.11, p. A9.

A. Słojewska, "Dżihad wprost z Brukseli”, Rzeczpospolita 2015, 17.11, p. A6.

P. Moszyński, "Co planowali terroryści z Paryża”, Gazeta Wyborcza 2015, 26.11, p. 11.

T. Bielecki, "Paryż szuka sojuszników”, Gazeta Wyborcza 2015, 24.11, p. 12.

P. Moszyński, "Dossier terrorystów z Paryża”, Gazeta Wyborcza 2015, 17.11, p. 10. 


\section{The objectivity principle}

The objectivity principle is expressed in the alignment of a journalistic report with the actual status of the discussed object or phenomenon. Therefore, the author presents the reality regardless of her/his views, and reliably reports on various points of view ${ }^{26}$. If a journalist is supposed to cope with the challenge of objective description of reality, she/he must, first of all, consider the wellknown " $5 \mathrm{Ws"} \mathrm{journalistic} \mathrm{principle} \mathrm{as} \mathrm{a} \mathrm{foundation} \mathrm{of} \mathrm{her/his} \mathrm{work.} \mathrm{According}$ to it, she/he must answer the five questions: who, where, when, why, what $2^{27}$. Secondly, the author of a press text ought to present events in the appropriate context, which includes organising individual pieces of information, and their most complete interpretation. The objectivity principle must therefore assume an aggiornamento, i.e. correcting the theory through applying it to an ever increasing

M. Czarnecki, "132 ofiary terrorystów. Większość zidentyfikowano", Gazeta Wyborcza 2015, 16.11, p. 3.

[editorial board], "Tragiczne zamachy w Paryżu”, Newsweek Polska 2015, Issue 47, 16.11-22.11, p. 4. M. Nowicki, "Paryż w stanie wojennym”, Newsweek Polska 2015, Issue 48, 23.11-29.11, pp. 62-68. M. Ostrowski, J. Winiecki, Ł. Wójcik, “Szarość, czerń i biel”, Polityka 2015, Issue 47, 18.11.-24.11, pp. 6-8.

The theme of Islam and the problem of terrorism were discussed in the following press texts:

P. Jendroszczyk, "Boko Haram ocieka krwią", Rzeczpospolita 2015, 20.11, p. A13.

P. Jendroszczyk, "Izrael ignoruje dżihadystów", Rzeczpospolita 2015, 19.11, p. A10.

J. Bielecki (interview with Alain Finkielkraut), "Fala uchodźców wygna Żydów z Francji”, Rzeczpospolita 2015, 18.11, p. A12.

M. Zawadzki (interview with Brian Katulis), “To był szczyt możliwości kalifatu”, Gazeta Wyborcza 2015, 16.11, p. 4.

R. Stefanicki (interview with Piotr Balcerowicz), "Państwo Islamskie. Dlaczego oni wygrywają", Gazeta Wyborcza 2015, 21.11-22.11, pp. 12-14.

K. Staszak (interview with Thomas Guénolé), "Liberté. A gdzie fraternité i égalité. Apartheid à la française", Gazeta Wyborcza 2015, 21.11-22.11, pp. 16-17.

A. Dębowska (interview with Krzysztof Rutkowski), "Paryża nie da się zniszczyć", Gazeta Wyborcza 2015, 20.11, pp. 30-31.

J. Pawlicki, “Terroryści w Brukseli”, Newsweek Polska 2015, Issue 48, 23.11-29.11, pp. 72-74.

M. Kacewicz, "Dżihadystan”, Newsweek Polska 2015, Issue 48, 23.11-29.11, pp. 75-77.

T. Targański, “Ogień zwalczany ogniem”, Polityka 2015, Issue 49, 2.12-8.12, pp. 64-66.

Piotr Jendroszczyk is a permanent collaborator of the foreign affairs department of Rzeczpospolita, previously a Berlin and Moscow correspondent. Alain Finkielkraut is a French writer, philosopher, essayist, a member of The Académie française, and a long-term commentator on social phenomena in France. Piotr Balcerowicz is a professor at the Faculty of Oriental Studies, University of Warsaw. Thomas Guénolé is a French political scientist working at the Paris Institute of Political Studies.

26 "Karta Etyczna Mediów"; I. Dobosz, op. cit., p. 132.

${ }^{27}$ P. Lewandowski, "Creative writing informacyjnych tekstów dziennikarskich", Wydawnictwo internetowe e-bookowo, 2014, pp. 55-56. 
collection of new facts ${ }^{28}$. Thus to be objective in the journalistic sense means to possess the skills of collecting material and assigning it specific meaning ${ }^{29}$. The above-mentioned principles may be visible, and the degree of their fulfilment can be evaluated based on the comprehensive narration of a periodical. That would mean an evaluation of the implementation of the journalistic objectivity principle, which is verified through the analysis of a series of press publications. Then, individual press texts are treated as elements forming a mosaic, a bigger whole, which possesses an inherent coherence of the series of the publications or a lack of it.

Therefore, I ventured to specify whether the analysed dailies Rzeczpospolita and Gazeta Wyborcza and opinion-making weeklies Newsweek Polska and Polityka considered in the form and content of their texts what happened in Paris the general experience and the cognitive horizon of the terrorist attacks, whether they included various contexts of the tragic events of 13 November 2015 in which they could be interpreted, i.e. had the previously mentioned aggiornamento taken place. I believe that by answering those questions, it will be possible to specify whether the analysed periodicals respected the objectivity principle. One should also add that the applied approach of journalistic objectivity corresponds to the synthesis of the concepts of functional objectivity, actual objectivity, and consensus as developed by Wolfgang Donsbach ${ }^{30}$.

\section{Fulfilling the 5Ws principle}

All of the analysed periodicals fulfilled the journalistic $5 \mathrm{Ws}$ principle. The texts informed the reader what happened on 13 November 2015 in Paris $(w h a t)^{31}$, provided a detailed account of the events, information about the organisation and the names of

\footnotetext{
${ }^{28}$ W. Furman, "Obserwator czy uczestnik? Dwa podejścia do obiektywizmu dziennikarskiego", Polityka i Spoleczeństwo 2012, Issue 9, p. 100, http://www.politologia.univ.rzeszow.pl/uploadUC/PiS/nr\%209/artykuly/Wojciech_Furman.pdf [accessed on: 27.01.2017].

${ }^{29}$ Ibid., pp. 100-101.

${ }^{30}$ M. Kunczik, A. Zipfel, "Publizistik. Ein Studienbuch”, Böhlau Verlag, Köln 2001, p. 279 as quoted in W. Furman, op. cit., p. 102.

${ }^{31}$ I shall quote selected fragments of the press texts which explain to the reader what happened in Paris on 13 Nov 2015: "The French people are showing their unity and courage after the attacks: a large crowd marched behind a banner with the Paris motto: Fluctuat nec mergitur - tossed but not sunk" (M. Ostrowski, J. Winiecki, Ł. Wójcik, op. cit., p. 6.); "It is estimated that over 150 people died in Friday evening's terrorist attacks in Paris" ([editors], op. cit., p. 4.); "At least 129 people died at five locations in the capital. It is the biggest terrorist attack in the country to date. The Islamists first struck on Friday at 9:20 p.m. At that time, one of the terrorists blew himself up near the Stade de France where a football match between France and Germany was taking place" (J. Bielecki, "Wojna w centrum Paryża”, Rzeczpospolita 2015, 16.11, p. A3).
} 
those responsible for the attack $(w h o)^{32}$, precise time references of the terrorist attacks $(w h e n)^{33}$ and their location (where $)^{34}$, as well as the reasons for the attacks (why $)^{35}$.

\section{The context of the reported events}

The reported events of 13 November 2015 and the situation in France after the terrorist attacks were presented in different contexts, i.a. in the political context (the policy of president François Hollande, political groups in France, relations with Russia and the

${ }^{32}$ I quote some fragments of the press texts which confirmed the who category in relation to the analysed topic (who performed the terrorist attacks): "The Friday attacks were the biggest attacks in France since WWII. At least 132 people died, and approx. 350 were injured. 'It was an act of war. It was committed by Islamic State', president François Hollande announced. Soon afterwards, jihadists took responsibility for the attack" (T. Bielecki, "Zamach na Europę", Gazeta Wyborcza 2015, 16.11, p. 1).

33 The when was represented in the following press texts: [AP, Reuters, BBC], "Kalendarium zamachów w Paryżu", Gazeta Wyborcza 2015, 16.11, pp. 4-5; J. Bielecki, "Francja się zachwiała", Rzeczpospolita 2015, 16.11, p. A1; J. Bielecki, "Wojna w centrum Paryża”, op. cit., p. A3.

${ }^{34}$ The following are some of the fragments of press texts referring to the where category: "At 9:25 p.m. a three-person unit driving a black Seat killed 15 people in front of the Le Carillon cafe-bar and the Le Petit Cambodge restaurant, at 9:32 p.m. five people in the garden of Café Bonne Bière, and at 9:36 p.m. the same assassins shot at the guests sitting on the patio of the La Belle Equipe restaurant, killing 19 people and severely injuring 9. The attack on the Stade de France where a friendly game with Germany was being held and the president was present in the stands (and where in seven months' time Euro 2016 is to commence), and on the Bataclan theatre were more thought through. At the stadium, the plan clearly fell apart and two attackers detonated their suicide belts. At Bataclan (the previous owner of which was considered pro-Israel), where hostages were held and which was eventually assaulted, the most people died. As we are writing this, there are a total of 129 casualties and over 350 injured" (M. Ostrowski, J. Winiecki, Ł. Wójcik, op. cit., p. 6).

35 The why was represented in the following press texts: "Islamic State stated its strategy in the February issue of the Dabiq magazine. Its promoters wrote there that "the goal of goals" is to eliminate the grey zone. It includes all those who have not declared yet whether they support good or evil, meaning Allah or they oppose the Prophet. The jihadists are so efficient in Syria and Iraq because they take advantage of all local fissions: ethnic, tribal and religious, to remove the grey zone. 'A divided community where hatred evokes fear is the perfect area for recruiting new fighters', wrote the wise men of IS" (M. Ostrowski, J. Winiecki, Ł. Wójcik, op. cit., pp. 6-7); "It is the poverty and a lack of any prospects in the French suburbs that thrust young people into the hands of Islamic extremists. [...] At the same time, according to an April report by the French Senate, approx. 1,430 out of 3,000 Europeans in total who fight in jihadist units in Syria and Iraq are French nationals. And many of those are actually inhabitants of the so-called banlieues - the poor suburbs of French cities dominated by immigrants. It does not take much for the young people frustrated with their lack of any prospects to believe that if they join jihad, all their problems will be solved" (M. Rębała, "Nie dyskryminować, tylko rewitalizować", Gazeta Wyborcza 2015, 16.11, p. 6); "At least we know why it was us who were attacked - because France was the only country in Europe apart from the United Kingdom to possess a fully-fledged defence system. And the UK, which made a mistake supporting George Bush regarding Iraq in 2003, has withdrawn to its island. No other EU Member State apart from France sends its troops to fight jihad" (I. Guetta, "Wiemy, dlaczego to nas zaatakowano", Gazeta Wyborcza 2015, 16.11, p. 2). 
EU, the attitude of Polish political groups towards the Paris attacks and the presence of Muslims in Europe), the historical context (previous acts of terrorism which had occurred in France), the cultural and social context (France as a model of an open society, the issue of immigration and refugees, the ripples of the events of 13 Nov 2015 in other European states), and the religious context (the essence of Islam and jihad).

\section{The political context}

A few press texts associated the acts of terror of 13 Nov 2015 with the increasing support for Marine Le Pen's National Front:

The leader of the National Front is actually using the effect: "I told you so." She just stated that "whatever the EU would do, France has to define its policy on its own," and demanded ad hoc measures to "annihilate Islamic extremism." Nicolas Sarkozy, the leader of the largest opposition party, has to struggle through such slogans propagated by right-wingers. He demands severe punishments even for those who browse jihadist websites. He also accuses the government of not being up to the task, and thus he suggests extensive corrections to French foreign policy: Putin, as the former French president has been stating for a long time now, is our ally in Syria. Without Russia we will not succeed in the fight against Daesh (Daesh is the scornfully-sounding Arabic acronym of Islamic State), neither will we become successful in coping with other major challenges posed before the international community ${ }^{36}$.

"The National Front means the return of Vichy France," warned Jean-Christophe Cambadélis, leader of the socialist party. In the first leg of the regional elections, candidates of the FN, the leader of which is Marine Le Pen, won first place in six out of 12 regions (excluding Corsica). It is true that they never acquired an absolute majority (in opinion polls, the FN received on average less than 30 percent of votes nationwide) nonetheless it was the highest result the party has ever gained, much better than that of the two mainstream parties: the ruling socialists and Sarkozy's Republicans ${ }^{37}$.

[On Sunday] the French went to vote in regional elections, which usually receive little attention, yet after the terrorist attacks they gained new significance. The vote became a trial of the rule of the socialists, and a test of the popularity of the extreme right-wing National Front ${ }^{38}$.

\footnotetext{
${ }^{36}$ M. Ostrowski, J. Winiecki, Ł. Wójcik, op. cit., p. 8.

${ }^{37}$ M. Ostrowski, "Front przeciw Frontowi", Polityka 2015, Issue 50, 09.12-15.12, p. 6.

${ }^{38}$ M. Rębała, “Strach pcha Francję na prawo”, Gazeta Wyborcza 2015, 07.12, p. 12.
} 
"The Paris attacks were a gift from the heavens for them. They help PiS (Law and Justice) as they fuel xenophobia. And Poles dislike foreigners, they do not want them in their backyards," said Jerzy Skoczylas, a Krakow-based journalist. He was shocked with the outright joy with which right-wing journalists wrote that the French had only got what they deserved! It serves them right since they have been letting immigrants in for years! ${ }^{39}$

PiS officials are covertly backing out of what Konrad Szymański, the expected new minister for European affairs, said right after the Paris attacks when he announced that Poland shall not fulfil the EU arrangements regarding receiving immigrants ${ }^{40}$.

In France, the state of emergency has just been extended. It is supposed to last three months. In Saint-Denis, a successful man hunt was carried out, during which the organiser of the attacks of 13 November died. French fighters are bombing the capital of the Islamic caliphate. "In these circumstances, not only mainstream rightwingers, but also the National Front will have trouble criticising the government and the president. It is clear that it is Hollande who holds the front line in the fight against Islamic State, both domestically and abroad. And that considerably limits Marine Le Pen's choices," said Guetta. Just like many other French, he also wants to believe in Hollande. The problem is that after the previous attacks or after the intervention in Mali in 2013, the ratings of the socialist president rose for a moment only to fall once again ${ }^{41}$.

Guy Sorman noted that the terrorist attacks in Paris should be viewed as a political victory for Russia, and in the context of the long-term negligence of the French and Belgian internal policies, and their passivity in the face of the "huge crowd of candidates ready to die a martyr's death in Europe" ${ }^{\prime 42}$.

Gazeta Wyborcza reported on a demonstration of Poznań nationalists who opposed the presence of Muslims in Poland, and on the reaction of Muslims:

"It was a great pain to see the attacks in Paris unfold. But it also pains us to see that some Poles blame us for that," said a Poznań-based imam during a Muslim demonstration. [...] During their demonstration, nationalists in Mickiewicz Square chanted: Polska wielka, Polska biała, bez Murzyna i pedała! (Great Poland, White Poland, without Niggers or Queers!), Wielka Polska, katolicka! (Great Catholic Poland!), Nie

${ }^{39}$ R. Kim, E. Lis, “Wcześniej się nie zdarzyło", Newsweek Polska 2015, Issue 48, 23.11-29.11, p. 33 .

${ }^{40}$ P. Wroński, "PiS szokuje w sprawie uchodźców”, Gazeta Wyborcza 2015, 16.11, p. 7.

${ }^{41}$ M. Nowicki, "Paryż w stanie wojennym", op. cit., p. 68.

${ }^{42}$ M. Nowicki (interview with Guy Sorman), "Wygrał Putin i terroryści”, Newsweek Polska 2015, Issue 48, 23.11-29.11, pp. 70-71. 
tęczowa, nie czerwona, tylko Polska narodowa! (Not a Rainbow, Nor Red, but a Nationalist Poland!), Polska tylko dla Polaków! (Poland only for Poles!), Ewangelia, a nie Koran! (The Scripture not the Quran! ${ }^{43}$.

Gazeta Wyborcza indicated that the terrorist attacks in Paris were used by Central Asian authoritarian regimes to limit civil liberties:

On Wednesday, the parliament of Tajikistan passed amendments to the act on combating terrorism. Now, in the event of a terrorist threat, the secret service can block the internet and cellular lines - both in selected locations and nationwide ${ }^{44}$.

Rzeczpospolita presented the proposal made by PiS regarding the radicalisation of the positions regarding refugees by the EU Member States in the context of the Paris attacks ${ }^{45}$.

\section{Historical context}

The article by Tomasz Targański entitled "Ogień zwalczany ogniem" discussed a bloody attack on a passenger train on 18 Jun 1961 in the context of the French-Algerian conflict, the activities of the Organisation armée secrète, and the National Liberation Front ${ }^{46}$.

In Paris, the word "war" keeps reappearing - it is present on the front pages of newspapers and in everyday discussions. In a dramatic speech delivered soon after the attacks, President François Hollande used it more than 10 times. The state of emergency was introduced for the first time since 1961 when extreme right-winged generals attempted to overthrow President de Gaulle ${ }^{47}$.

\footnotetext{
${ }^{43}$ P. Żytnicki, T. Nyczka, J. Leśniewska, “Muzułmanie przeciwko terroryzmowi”, Gazeta Wyborcza 2015, 30.11, p. 5.

${ }^{44}$ A. Poczobut, "Walka z terroryzmem wzmacnia dyktatorów", Gazeta Wyborcza 2015, 28-29.11, p. 17.

${ }^{45}$ A. Stankiewicz, "PiS apeluje o zamknięcie granic", Rzeczpospolita 2015, 16.11, p. A7.

46 T. Targański, op. cit., pp. 64-66.

${ }^{47}$ M. Nowicki, "Paryż w stanie wojennym", op. cit., p. 64.
} 


\section{Cultural and social contexts}

In his statement which has already resonated throughout the continent, Konrad Szymański, the expected new Polish minister for European affairs, stated that after the Paris attacks he sees no political possibility of Poland accepting any immigrants based on previous EU arrangements. And even though Szymański later tempered his words, the immigrant - terrorist association has permanently entered the political main stream ${ }^{48}$.

During a recent demonstration on Polish Independence Day, he [doctor Ziad Abou Saleh from Syria] felt uneasy about such a scene: a sea of white-and-red flags and among them a banner stating: Polska dla Polaków (Poland for the Poles). "I have been living in Poland for over 30 years and nothing like that has ever happened here. It began during the election campaign when a considerable portion of the politicians spoke terribly of refugees only to increase their poll ratings. And thus they conceded to the youth going through the streets and freely, without any moral dilemma, saying that Poland should be white and Catholic," argued Dr. Abou Saleh ${ }^{49}$.

The article entitled "Islamska emigracja z Francji" discussed the anti-Muslim tendencies in France based on the accounts of Stowarzyszenie przeciwko Islamofobii (Association Against Islamophobia) ${ }^{50}$.

In the context of anti-Muslim attitudes, Jacek Hołub discussed in Gazeta Wyborcza the position of the Radio Maryja radio station:

The topic of the menacing Muslim "illegal immigrants" ousted from Radio Maryja's banners its main slogan: the fight against the "gender ideology." Now, a day before the $24^{\text {th }}$ anniversary of the station, which will be celebrated on Saturday in Torun, the Redemptorist [fr. Tadeusz Rydzyk - translator's remark] has a new enemy. It is the "liberal multicultural ideology", the political proponents of which have led to the settling in the west of Europe millions of Muslims and they want to accept even more ${ }^{51}$.

Jerzy Haszyczński posed a question regarding European civil liberties in the context of the Paris terrorist attacks:

Once again we are faced with a dilemma in our fight against terror: how far can one dispense with Western freedom and values to increase security and eliminate the

\footnotetext{
${ }^{48}$ M. Ostrowski, J. Winiecki, Ł. Wójcik, op. cit., p. 8.

${ }^{49}$ R. Kim, E. Lis, "Wcześniej się nie zdarzyło", op. cit., p. 34.

${ }^{50}$ M. Rębała, "Islamska emigracja z Francji”, Gazeta Wyborcza 2015, 11.12, p. 21.

${ }^{51}$ J. Hołub, "Teraz islamizacja”, Gazeta Wyborcza 2015, 05.12-06.12, p. 6.
} 
threats? Also, to what extent can one dispense with the principles, such as freedom of movement, which apply in the EU, where a leading Member State was ruthlessly attacked? $?^{52}$

\section{Religious context}

After the 9/11 attacks, there appeared a category of "Arabs" in CBOS surveys regarding the attitude of Poles towards other nations. From that moment on Arabs, interchangeably with the Romani, have been the least liked national group - reminded Dr Katarzyna Górak-Sosnowska, specialist on Islam at the Warsaw School of Economics. However, she did note that regardless of the aversion to Muslims, Islamophobic slogans remained for a long time a fringe issue: "Now, they have reached the main stream, they have become a rational, sanctioned voice in the dispute on Islam" 53 .

In an article entitled "Terroryści w Brukseli", Jacek Pawlicki discussed how jihadists perceived their own situation while living in Europe:

"Those people perceive themselves as the victims of discrimination and racism," explained Montasser AlDe'emeh in an interview with a Belgian newspaper. The Jordan-born Palestinian living in Molenbeek is a recognised researcher of Belgian Islamic movements. He argued that for many years they have been recruiting young people from the fringes of Belgian society. ISIS's message which reaches young Muslims via social media or through their colleagues is simple: in Belgium, you are nobody, in Syria you can be heroes and Mujahideen (holy warriors) ${ }^{54}$.

In an article entitled "Dżihadistan", Michał Kacewicz extensively discussed the nature of Islamic State and its members:

They manufacture their own gold coins, they pay our pensions, they possess a proprietary intelligence, and a 100,000-strong army. They finance jihad from ransom, and trading oil and stolen works of art. [...] Abu Bakr al-Baghdadi (which means "originally from Baghdad"), the leader of Islamic State, wears black robes during official events reminiscent of the historical dress of Sunni rulers. But on an everyday basis, he wears a field uniform and is surrounded by bodyguards. He is constantly on the move. He does not use a cellular phone or the internet. Eighteen months ago he

\footnotetext{
52 J. Haszczyński, “Dżihadyści uderzyli w zachodni styl życia”, Rzeczpospolita 2015, 16.11, p. A6.

${ }^{53}$ R. Kim, E. Lis, "Wcześniej się nie zdarzyło", op. cit., p. 3.

${ }^{54}$ J. Pawlicki, op. cit., p. 74.
} 
assumed the title of caliph Ibrahim - for Sunnis it was an important symbol of the revival of the caliphate, i.e. the great homeland of all Muslims. He controls over 80,000 sq. $\mathrm{km}$ of Syria and Iraq, an area which is inhabited by 8 million subjects. Emulating the long-gone rulers, he established the Muslim council, which is similar to a government and a judicial tribunal. It has ministries and field administration. [...] By bringing back the notion of Arabic unity, the self-appointed caliph gained the sympathy of those communities which have never been that radical. Islamic State has received the support of both officers of the former Iraqi army of Saddam Hussein, and young Syrian revolutionaries. The former are frustrated in that after the American invasion of Iraq in 2003 they lost their privileged position, particularly when the invaders gave the rule to Shias. The latter saw in Islamic State an efficient organisation capable of defeating the dictator. Even more so since jihadists managed to eliminate the banditry which had been raging for a long time in the seized territories. "Syrian and Iraqi peasants were relieved to welcome Islamic State's arrival, as it offered relative peace and order in the seized territories," said Olivier Hanne. The price for peace was the introduction of sharia (Islamic law) and brutal removal of any forms of resistance. In the centre of Syrian Raqqa, the Islamists' stronghold, horrific spectacles of the crucifixion of people suspected of espionage are organised. Women are stoned for having a Facebook account, and homosexuals are thrown off of roof tops. The streets are patrolled by Muslim police units, including the female al-Chansa brigade, making sure,e.g. women are not using any prohibited contraceptives. However, healthcare and schools do work, though children learn there only the principles of Islam and its history. Social aid is paid out (e.g. a 10-dollar benefit for every child) ${ }^{55}$.

The reported events together with new information regarding the circumstances of the attacks were organised and interpreted in a more comprehensive context in the analysed periodicals. In the first issue of Newsweek Polska, i.e. $47 / 2015$, after the bomb attacks, it was not specified who had been responsible for them: "When we were closing this issue of Newsweek, we still did not know the final number of casualties. Unknown perpetrators fired automatic firearms in several locations throughout the city" ${ }^{56}$. Only the following issue of the weekly included the more comprehensive context of the attacks. Gazeta Wyborcza provided details of the investigation on an on-going basis: "The investigation into the Paris attacks offers new details sporadically. Abdelhamid Abaaoud, their mastermind, not only participated in them, but even returned to the crime scene" "B7; "Belgians are still on the hunt for Salah Abdeslam - the only jihadist who survived the terrorist attacks in Paris. And President François Hollande is trying to put together

\footnotetext{
${ }^{55}$ M. Kacewicz, op. cit., pp. 75-76.

56 [editorial board], op. cit., p. 4.

${ }^{57}$ P. Moszyński, “Co planowali terroryści...”, op. cit., p. 11.
} 
a coalition against Islamic State" ${ }^{98}$. Regular updates particularly referred to information regarding those responsible for conducting the attacks (contacts with the Belgian Molenbeek ghetto):

Last Monday, armoured Belgian police vehicles once again took to the streets of Molenbeek, and fully armed police special forces leapt with machine guns over balconies and roofs. Despite the show of force, they were unable to apprehend the 26-year-old Salah Adbelslam, the only Paris attacker still living. His brother Ibrahim blew himself up in the Paris Boulevard Voltaire, while Salah managed to return to Brussels. [...] It is hardly a surprise for anyone that Salah returned to his borough. According to Bilal Benyaich, a Belgian expert on radical Islam: "Molenbeek is a place where you can disappear easily." That is the location of the majority of the blank spots of Brussels, where the police rarely venture, and which are ruled by drug gangs and arms dealers. He went on to explain that Molenbeek had not become the centre of European jihad without a reason. It is the perfect operating base: from the centrally located Brussels, it is close to all the major capitals of the West. It possesses a strong ideological centre - 22 mosques plus several underground prayer houses, where Salafi imams preach. In the flourishing black market, it is easy to acquire an AK-47 and ammunition. Benyaich is certain that if you know on which door to knock, you can buy an AK-47 for 500-1,000 euros. The firearms were smuggled in the 1990s to Belgium from the Balkans via Germany... ${ }^{59}$

After almost every jihadist attack in Europe it turns out that some evidence leads to the Brussels borough of Molenbeek. That is also the case now - several suspects have just been arrested there in relation to the Paris attacks ${ }^{60}$.

Newspapers and magazines also included interpretations questioning the sense of fighting terrorism ${ }^{61}$. There also appeared the topic of supporting the antijihadist coalition ${ }^{62}$.

${ }^{58}$ T. Bielecki, "Paryż szuka sojuszników”, op. cit., p. 12.

${ }^{59}$ J. Pawlicki, op. cit., p. 72.

${ }^{60}$ T. Bielecki, "Modny adres bohemy i dżihadystów", Gazeta Wyborcza 2015, 17.11, p. 11.

61 "The Paris daily Le Monde included a series of opinions of acclaimed philosophers: Jürgen Habermas noted that Geogre Bush's version of the 'war on terror' damaged the political and mental condition of American society. Frédéric Gross warned that the war with terrorism should not lead to submitting to the 'logic of fear and hatred'. He made an appeal to maintain civil vigilance regarding police rights" ([editorial board], "Wolność na wojnie", Polityka 2015, Issue 48, 25.1101.12 , p. 5).

62 "The anti-jihadist coalition is growing in strength. The United Kingdom intends to join the bombings of Syria, while Germany wants to send up to 1,200 troops on a mission to fight Islamic State” (R. Stefanicki, "Brytyjczycy idą na wojnę za Paryż”, Gazeta Wyborcza 2015, 03.12, p. 13); From the neighbouring Belgium to which he fled after the attacks, news is coming in about a search 


\section{Conclusions}

In my case study, I found no social acceptance or legitimisation on the part of the media of the terrorist acts performed in Paris on 13 November 2015. The analysed Polish periodicals successfully fulfilled the objectives of a primary and secondary media outlet respecting the two main principles of journalistic ethics: the truth principle and the objectivity principle. That was confirmed by the quantitative and qualitative analyses. The reader was informed about what happened on 13 Nov 2015 in the capital of France. The terrorist attacks were discussed in various interpretative frames. The journalistic presentation of the events covered the political, historical, cultural, social, and religious contexts. The extensive overview of the topic of jihad was supplemented by texts helping readers understand how the members of the Islamic State terrorist organisation perceive their mission. It is noteworthy, that out of the 109 texts which met the methodological criteria of the analysis, none appeared prior to 13 November 2015.

The conducted study confirmed the journalists' efforts to ensure reliable reports on the facts in seeking the truth of the events of 13 Nov 2015 (answers to questions: what happened in Paris on 13 Nov 2015, who committed the attack, when the acts of terror occurred, where did they occur, why the attacks were committed) offering a diverse interpretative spectrum and a wide research horizon.

The undertaken analysis proved the grave role of the mass media in terrorist organisations' political communication. The categories of truth and objectivity used by the publishers are essential for the proper understanding of the core of the communication.

\section{Bibliography}

Altheide D., "The mass media and terrorism", Discourse \& Communication 2007, Issue 1 (3), pp. 287-308.

Borkowski R., “Terroryzm ponowoczesny. Studium z antropologii polityki”, Wydawnictwo Adam Marszałek, Torun 2006.

Castillo M., Haddad M., Martinez M., Almasy S., CNN, "Paris suicide bomber identified; ISI claims responsibility for 129 dead", http://edition.cnn.com/2015/11/14/world/paris-attacks/ index.html [accessed on: 27.01.2017].

Dobek-Ostrowska B., “Komunikowanie polityczne i publiczne”, PWN, Warsaw 2012.

for ten people suspected of preparing a similar terrorist operation to the one in Paris. Meanwhile, since Sunday, 143 heads of states and governments with delegations have arrived in Paris. Those will include the heads of all the states participating in military operations against Islamic State in Syria and Iraq" (P. Moszyński, "Szczyt w cieniu zamachów terrorystycznych", Gazeta Wyborcza 2015, 30.11, p. 15). 
Dobosz I., "Prawo i etyka w zawodzie dziennikarza", Oficyna Ekonomiczna Grupa Wolters Kluwer, Warsaw 2008.

Fiut I., "Spory o etykę mediów", in: "Spór o etykę. Materiały X Jagiellońskiego Sympozjum Etycznego. Kraków, 4-5 czerwca 1998”, J. Pawlica (ed.), Wydawnictwo Uniwersytetu Jagiellońskiego, Krakow 1999, pp. 65-72.

Furman W., "Obserwator czy uczestnik? Dwa podejścia do obiektywizmu dziennikarskiego", Polityka i Społeczeństwo 2012, Issue 9, p. 100, http://www.politologia.univ.rzeszow.pl/uploadUC/PiS/nr\%209/artykuly/Wojciech_Furman.pdf [accessed on: 27.01.2017].

Goban-Klas T., "Dziennikarze i terroryści - przeciwnicy czy wspólnicy?”, in: “Między odpowiedzialnością a sensacją. Dziennikarstwo i edukacja na przełomie wieków”, K. Wolny-Zmorzyński, M. Wrońska, W. Furman (eds.), Wydawnictwo Uniwersytetu Rzeszowskiego, Rzeszow 2006, pp. 19-23.

Gunaratna R., Steven G., "Counter-Terrorism: A Reference Handbook”, ABC-CLIO, Santa Barbara, California 2004.

Gunter J., Lukov Y., Poole T., Low H., Harrison E., Spender T., "Paris attacks: as they happened", http://www.bbc.com/news/live/world-europe-34815972 [accessed on: 27.01.2017].

Hoffman B., "Inside Terrorism”, Columbia University Press, New York 2006.

"Karta Etyczna Mediów", http://www.radaetykimediow.pl/index.php?option=com_content\&view $=$ category\&layout=blog\&id=2\&Itemid=3 [accessed on: 27.01 .2017 ].

Knecht E., "Islamic State says France remains top target", http://www.reuters.com/article/us-france-shooting-claim-idUSKCN0T30LL20151114 [accessed on: 27.01.2017].

Kunczik M., Zipfel A., "Publizistik. Ein Studienbuch”, Böhlau Verlag, Köln 2001.

Lewandowski P., "Creative writing informacyjnych tekstów dziennikarskich", Wydawnictwo internetowe e-bookowo, 2014, pp. 55-56.

Madej M., "Międzynarodowy terroryzm polityczny”, Ministerstwo Spraw Zagranicznych, Warsaw 2001.

Maniszewska K., "Terroryzm a media. Środki masowego przekazu i literatura a rozwój terroryzmu w Republice Federalnej Niemiec w latach 1968-1998”, Oficyna Wydawnicza „Atut” - Wrocławskie Wydawnictwo Oświatowe, Wroclaw 2006.

Mroczek A., "Media”, in: “Terroryzm. Anatomia zjawiska”, K. Liedel (ed.), Wydawnictwo Naukowe Scholar, Warsaw 2006, pp. 240-243.

Nacos B., "Mass-Mediated Terrorism: The Central Role of the Media in Terrorism and Counterterrorism", Lanham, Maryland 2007.

Peresin A., "Mass media and Terrorism", Medijska istraživanja 2007, Vol. 13, Issue 1, pp. 5-22, http://hrcak.srce.hr/file/28073 [accessed on: 27.01.2017].

Sasińska-Klas T., "Mediatyzacja a medializacja sfery publicznej”, Zeszyty Prasoznawcze 2014, Issue 2, pp. 162-175.

\section{Internet sources}

[AP, Reuters, BBC], “Kalendarium zamachów w Paryżu”, Gazeta Wyborcza 2015, 16.11, pp. 4-5. Bielecki J. (interview with Alain Finkielkraut), “Fala uchodźców wygna Żydów z Francji”, Rzeczpospolita 2015, 18.11, p. A12.

Bielecki J., "Francja się zachwiała", Rzeczpospolita 2015, 16.11, p. A1.

Bielecki J., "Nowa religia nadziei dla francuskich przedmieść", Rzeczpospolita 2015, 30.11, p. A10.

Bielecki J., “Śmiertelny wyścig z dżihadem”, Rzeczpospolita 2015, 19.11, p. A9. 
Bielecki J., "Wojna w centrum Paryża”, Rzeczpospolita 2015, 16.11, p. A3.

Bielecki T., "Modny adres bohemy i dżihadystów”, Gazeta Wyborcza 2015, 17.11, p. 11.

Bielecki T., "Paryż szuka sojuszników”, Gazeta Wyborcza 2015, 24.11, p. 12.

Bielecki T., "Zamach na Europę", Gazeta Wyborcza 2015, 16.11, p. 1.

Czarnecki M., "132 ofiary terrorystów. Większość zidentyfikowano", Gazeta Wyborcza 2015, 16.11, p. 3.

Dębowska A. (interview with Krzysztof Rutkowski), "Paryża nie da się zniszczyć", Gazeta Wyborcza 2015, 20.11, pp. 30-31.

[editorial board], “Tragiczne zamachy w Paryżu”, Newsweek Polska 2015, Issue 47, 16.11-22.11, p. 4.

[editorial board], "Wolność na wojnie", Polityka 2015, Issue 48, 25.11-01.12, p. 5.

Guetta I., "Wiemy, dlaczego to nas zaatakowano", Gazeta Wyborcza 2015, 16.11, p. 2.

Haszczyński J., "Dżihadyści uderzyli w zachodni styl życia”, Rzeczpospolita 2015, 16.11, p. A6.

Hołub J., “Teraz islamizacja”, Gazeta Wyborcza 2015, 05.12-06.12, p. 6.

Jendroszczyk P., "Boko Haram ocieka krwią", Rzeczpospolita 2015, 20.11, p. A13.

Jendroszczyk P., "Izrael ignoruje dżihadystów”, Rzeczpospolita 2015, 19.11, p. A10.

Kacewicz M., "Dżihadystan”, Newsweek Polska 2015, Issue 48, 23.11-29.11, pp. 75-77.

Kim R., Lis E., "Wcześniej się nie zdarzyło”, Newsweek Polska 2015, Issue 48, 23.11-29.11, pp. 32-35.

Moszyński P., "Co planowali terroryści z Paryża”, Gazeta Wyborcza 2015, 26.11, p. 11.

Moszyński P., "Dossier terrorystów z Paryża”, Gazeta Wyborcza 2015, 17.11, p. 10.

Moszyński P., "Szczyt w cieniu zamachów terrorystycznych”, Gazeta Wyborcza 2015, 30.11, p. 15.

Nowicki M. (interview with Guy Sorman), "Wygrał Putin i terroryści”, Newsweek Polska 2015, Issue 48, 23.11-29.11, pp. 70-71.

Nowicki M., "Paryż w stanie wojennym", Newsweek Polska 2015, Issue 48, 23.11-29.11, pp. 62-68.

Ostrowski M., "Front przeciw Frontowi”, Polityka 2015, Issue 50, 09.12-15.12, p. 6.

Ostrowski M., Winiecki J., Wójcik Ł., “Szarość, czerń i biel”, Polityka 2015, Issue 47, 18.11.-24.11, pp. 6-8.

Pawlicki J., “Terroryści w Brukseli”, Newsweek Polska 2015, Issue 48, 23.11-29.11, pp. 72-74.

Poczobut A., "Walka z terroryzmem wzmacnia dyktatorów", Gazeta Wyborcza 2015, 28-29.11, p. 17.

Rębała M., "Islamska emigracja z Francji”, Gazeta Wyborcza 2015, 11.12, p. 21.

Rębała M., "Nie dyskryminować, tylko rewitalizować”, Gazeta Wyborcza 2015, 16.11, p. 6.

Rębała M., "Strach pcha Francję na prawo", Gazeta Wyborcza 2015, 07.12, p. 12.

Słojewska A., "Dżihad wprost z Brukseli", Rzeczpospolita 2015, 17.11, p. A6.

Stankiewicz A., "PiS apeluje o zamknięcie granic", Rzeczpospolita 2015, 16.11, p. A7.

Staszak K. (interview with Thomas Guénolé), "Liberté. A gdzie fraternité i égalité. Apartheid à la française", Gazeta Wyborcza 2015, 21.11-22.11, pp. 16-17.

Stefanicki R. (interview with Piotr Balcerowicz), "Państwo Islamskie. Dlaczego oni wygrywają", Gazeta Wyborcza 2015, 21.11-22.11, pp. 12-14.

Targański T., “Ogień zwalczany ogniem”, Polityka 2015, Issue 49, 2.12-8.12, pp. 64-66.

Wroński P., "PiS szokuje w sprawie uchodźców”, Gazeta Wyborcza 2015, 16.11, p. 7.

Zawadzki M. (interview with Brian Katulis), “To był szczyt możliwości kalifatu”, Gazeta Wyborcza 2015, 16.11, p. 4.

Żytnicki P., Nyczka T., Leśniewska J., “Muzułmanie przeciwko terroryzmowi”, Gazeta Wyborcza $2015,30.11$, p. 5. 


\title{
Rafał Leśniczak
}

\section{Fulfilling the journalistic principles of truth and objectivity in the context of mediatisation of political communication - the terrorist attacks in Paris \\ in November 2015}

\begin{abstract}
(Summary)
The mediatisation of political communication indicates two main functions of the mass media: they report on events from the world of politics and create the images of political actors in the eyes of the public. I attempt to answer the question: can one talk about respecting the basic principles of journalistic ethics (the truth and the objectivity principles) in the times of the mediatisation of the public sphere? The theme of the article applies to terrorism, which is a form of political communication, having its own special expression. The activities of terrorist organisations influence the actions of the leaders of political life, citizens and the mass media. The research material consisted of Polish opinion-making weeklies Newsweek Polska and Polityka and national dailies in their printed versions: Gazeta Wyborcza and Rzeczpospolita. The time frame covered a period from 1 November 2015 to 11 December 2015. The topic of the article was treated as a case study.
\end{abstract}

Keywords: mass media, mediatisation, politics, truth, objectivity, communication. 